\title{
PELAKSANAAN SITA EKSEKUSI ATAS OBJEK JAMINAN HIPOTEK KAPAL LAUT YANG SEDANG DALAM KEGIATAN PELAYARAN
}

\author{
Muhammad Rizky Syahrur Rizal \\ Fakultas Hukum, Universitas Airlangga Surabaya \\ e-mail: rizky.syahrur@gmail.com
}

\begin{abstract}
ABSTRAK
Penelitian ini bertujuan untuk mengetahui segala jenis Eksekusi yang dapat diberlakukan terhadap objek jaminan yang dibebeni dengan Hipotek. Dari berbagai jenis eksekusi yang ditawarkan mulai dari Eksekusi dengan Titel Eksekutorial (yang berdasarkan adanya irah-irah dalam akta hipotek), yang kedua melalui Parate Eksekusi yang dapat dilaksanakan tanpa melalui jalur pengadilan, melainkan hanya dengan adanya kuasa menjual oleh kreditor, dan yang terakhir melalui penjualan di bawah tangan dengan kesepakan antara debitor dan kreditor untuk mencari pembeli dengan harga tertinggi. Berdasarkan hasil penelitian dapat disimpulkan bahwa dalam pelaksanaan eksekusi objek jaminan terkait wanprestasi yang diberikan tersebut masih tidak melindungi kepentingan Kreditor. Di mana dalam hal ini ketika objek jaminan tersebut masih dalam kegiatan bongkar muat dan pelayaran. Ketika dalam proses kegiatan bongkar muat, kapal tidak dapat dilaksanakan Eksekusi atas objek jaminan tersebut. Selain itu terdapat kendala lain, yaitu manakala objek jaminan tersebut sedang berlayar, baik di perairan Indonesia ataupun di Luar Negeri, akan mempersulit eksekusi objek jaminan tersebut. Sehingga dari beberapa kendala di atas dapat semakin melemahkan posisi Kreditor. Penelitian ini merupakan penelitian normatif. Hasil yang didapatkan dari penelitian ini adalah diperlukan penafsiran ketentuan peraturan Hipotek kapal dan juga ratifikasi konvensi internasional yang terkait, agar tidak ada lagi kekosongan hukum
\end{abstract}

Kata Kunci: Hipotek; Kapal Laut; Eksekusi

\section{ABSTRACT}

This study aims to determine all types of Execution that can be applied to the object of collateral that is provided with a Mortgage. From the various types of executions offered starting from Execution with Executive Titles (which are based on the existence of irregularities in the mortgage deed), the second through Parate Execution which can be carried out without going through the court, but only with the power of selling by creditors, and the last through sales with agreements between debtors and creditors to find buyers with the highest prices. Based on the results of the study it can be concluded that in the execution of the object of collateral related to the default given still does not protect the interests of the creditor. Where in this case when the object of guarantee is still in loading and unloading activities. When in the process of loading and unloading, the ship cannot be executed Execution of the object of the guarantee. In addition, there are other obstacles, namely when the object of guarantee is sailing, whether in Indonesian waters or abroad, it will complicate the execution of the object of the guarantee. So that from some of the obstacles above can further weaken the position of creditors. This research is normative research. The results obtained from this study are necessary to interpret the provisions of ship mortgage regulations and also the ratification of relevant international conventions, so that there will be no more legal vacancies

Keywords: Mortgage; Ship; Execution 


\section{PENDAHULUAN}

Hipotek kapal laut saat ini merupakan suatu urgensi bagi Negara Indonesia untuk dikembangkan peraturannya. Hal ini didasarkan pada beberapa pelaksanaan dari Jaminan Hipotek kapal laut tidak mampu berlaku efektif dan cenderung mengalami hambatan.

Berdasarkan Pasal 8 Undang-Undang Nomor 7 Tahun 1992 yang telah dirubah dengan UndangUndang No. 10 Tahun 1998 tentang Perbankan (selanjutnya disebut UU Perbankan) mengatur bahwa bank dalam hal memberikan kredit juga wajib mempertimbangkan prinsip $5 \mathrm{C}$ atau sering disebut dengan Prudential Banking, prinsip 5C ini digunakan bank untuk mengukur apakah debitor sanggup dan mampu melunasi hutang bank, prinsip tersebut antara lain yaitu Character, Capacity, Capital, Collateral, dan Condition. Salah satu prinsip yang diutamakan dari kelima prinsip di atas adalah Collateral, prinsip ini yaitu mengenai beda agunan.

Prinsip ini terwujud dalam bentuk adanya permintaan jaminan dari bank demi kelancaran dan kepastian pelunasan hutang. Jaminan yang diharapkan tentu saja jaminan yang berdaya guna dan merupakan benda modal. Penggunaan jaminan, tentunya harus berdasarkan bingkai hukum yang berlaku, bingkai hukum untuk jaminan yaitu Hukum Jaminan, yang mana aturan dasarnya terletak pada Buku II Burgerlijk Wetboek (selanjutnya disebut BW). Jaminan ini kerapkali terkait dengan benda, walaupun tidak selalu harus benda yang dijaminkan.

Pengaturan dalam BW mengadakan pembagian benda, pembagian benda yang terpenting adalah benda bergerak dan tidak bergerak, hal ini karena berkaitan dengan Bezit (Pasal 1977 BW), Bezwaring (Pasal 1150-1232 BW), Beslag (Pasal 197 Herziene Indonesisch Reglement (selanjutnya disingkat HIR)), Levering (Pasal 612, 613, 616 BW), dan Verjaring (Pasal 610 jo. 1946, 1963, 1969 BW).

Mengenai Bezwaring (penjaminan), juga diadakan penggolongan berdasarkan benda bergerak dan tidak bergerak. Lembaga jaminan untuk benda bergerak yaitu Gadai (diatur dalam Pasal 1150-1160 BW) dan Fidusia (diatur dalam Undang-Undang Nomor 49 Tahun 1999 tentang Fidusia (selanjutnya disebut UUJF) ). Sedangkan lembaga jaminan untuk benda tidak bergerak yaitu Hipotek (diatur dalam Pasal 1162-1232 BW) dan Hak Tanggungan (diatur dalam Undang-Undang Nomor 4 Tahun 1996 tentang Hak Tanggungan (selanjutnya disingkat UUHT)). ${ }^{1}$

Berkaitan dengan penjabaran sebelumnya, para pelaku bisnis pelayaran yang membutuhkan modal dan mengajukan peminjaman dana kepada Bank, kerapkali menyikapi adanya syarat jaminan ini dengan menjaminkan kapal laut yang dimilikinya, dengan harapan dapat disetujui permohonan kreditnya. $^{2}$

Mengingat bidang usaha yang dijalani adalah bisnis pelayaran, maka jaminan yang disediakan untuk kapal laut adalah Hipotek. Pasal 314 Wetboek van Koophandel (selanjutnya disebut WvK), menegaskan bahwa kapal laut dengan isi kotor sekurang-kurangnya $20 \mathrm{~m}^{3}$, dapat dibebani dengan Hipotek. Hal ini juga diungkapkan oleh Moch. Isnaeni dalam bukunya: "Sesuai kewenangan yang dimiliki oleh pembentuk undang-undang, maka ditetapkanlah bahwa kapal dengan bobot kotor tidak kurang dari $20 \mathrm{~m} 3$, kalau dijadikan agunan, lembaga Hipotek yang digunakan. Seluk beluk jaminan kapal ini dalam WvK diatur mulai Pasal 314 sampai dengan 315 e. $^{3}$

Dengan memahami karakter bagaimana kapal bekerja di atas perairan, bukan hal yang tidak mungkin dahwa kapal tersebut dapat menjelajah sewaktu-waktu apabila menerima muatan untuk dapat dikirimkan ke berbagai daerah di Indonesia maupun luar negeri. Kegiatan tersebut cukup menjadi perhatian khusus bagi pihak kreditor bilamana terjadi wanprestasi oleh debitor terhadap kewajibannya dikarenakan hal tersebut sangat berdampak terhadap kegiatan eksekusi terhadap objek yang telah dijaminkan. Eksekusi kapal yang sedang berlayar di perairan dalam negeri harus ditangguhkan bilamana kapal tersebut sedang bongkar muat barang. Ketentuan ini berdasarkan pada Pasal 315 (e) WvK dan Pasal 216 angka (1) Undang-Undang Nomor 17 Tahun 2008 tentang Pelayaran (selanjutnya disebut UU Pelayaran) yang menentukan bahwa kapal tidak boleh dilakukan eksekusi bilamana sedang bongkar muat.

${ }^{1}$ Fani Martiawan Kumara Putra. (2012). "Surat Kuasa Memasang Hipotek Dalam Jaminan Hipotek Kapal Laut”. Jurnal Perspektif. 17(2), 98-107.

2 ibid.

${ }^{3}$ Moch. Isnaeni. (1996). Hipotek Pesawat Udara di Indonesia. Surabaya: Dharma Muda, h. 32. 


\section{PERUMUSAN MASALAH}

Berdasarkan uraian singkat latar belakang di atas, maka dalam penelitian ini dapat dirumuskan masalah yang akan dibahas nantinya, yaitu pelaksanaan sita eksekusi atas objek jaminan Hipotek kapal laut yang sedang dalam kegiatan pelayaran.

\section{PEMBAHASAN}

\section{Kapal Laut Sebagai Objek Jaminan Hipotek}

Pada awal mulanya, Hipotek digunakan sebagai lembaga jaminan atas tanah, namun dengan diundangkannya UUHT maka terjadi perubahan, perubahan tersebut adalah obyek Hipotek tidak lagi berupa tanah, karena lembaga jaminan untuk tanah diambil alih oleh Hak Tanggungan. Batasan mengenai obyek Hipotek kini dijabarkan dalam Pasal 29 UUHT, bahwa Hipotek dan Credietverband sepanjang menyangkut benda tanah dan segala sesuatu yang melekat dengan tanah dinyatakan tidak berlaku lagi. Keberadaan Hipotek tetap eksis dengan obyeknya yaitu benda tidak bergerak yang tidak menyangkut benda tanah atau terkait dengan tanah, contoh pesawat terbang, helikopter, dan kapal laut. ${ }^{4}$

Kapal laut yang dapat dijadikan sebagai obyek Hipotek sifatnya terbatas, yaitu sesuai dengan pengaturan dalam Pasal 314 WvK, Kapal laut sebagai dengan isi kotor sekurang-kurangnya 20 $\mathrm{m}^{3}$ (dua puluh meter kubik) dapat didaftarkan dalam register umum dan dijadikan obyek Hipotek. Pendaftaran terhadap kapal ini memberikan sifat hak kebendaan yang kuat kepada pemilik hingga dapat dipertahankan terhadap siapapun juga. Dalam praktiknya pendaftaran memberi perlindungan yang kuat kepada pemilik, karena pemilik dapat mempertahankan haknya terhadap publik (umum). Publik yang ingin mengetahui status kapal itu dapat mencari informasinya dari lembaga pendaftaran. Jika pendaftaran itu hapus, maka sifat hak kebendaan kapal tunduk pada ketentuan dalam Pasal 1977 BW."5

Bilamana ditelaah dari dasar pengaturan Pasal 1162 BW, yaitu Hipotek diperuntukkan bagi benda tidak bergerak, maka dapat diambil pengertian bahwa kapal laut dengan ukuran sekurangnya $20 \mathrm{~m}^{3}$ (dua

\footnotetext{
${ }^{4}$ Fani Martiawan Kumara Putra. (2012). loc.cit.

${ }^{5}$ Mariam Darus Badrulzaman. (1983). Beberapa Masalah Hukum dalam Perjanjian Kredit Bank dengan Jaminan Hipotek Serta Hambatan-hambatannya dalam Praktek di Medan. Bandung: Alumni, h. 265.
}

puluh meter kubik) dan terdaftar, dapat digolongkan menjadi benda tidak bergerak, walaupun sebenarnya dapat terlihat bahwa kapal laut merupakan benda bergerak. ${ }^{6}$ Pada dasarnya inti benda tidak bergerak adalah berorientasi pada tanah (Pasal 506, 507 dan 508 BW). Apabila dicermati lebih dalam lagi, pada masa sebelum hadirnya UUHT, tanah yang dapat dibebani Hipotek hanya sebatas pada tanah yang sudah terdaftar. Inilah sebenarnya dasar bahwa sesungguhnya obyek Hipotek itu sesungguhnya adalah benda terdaftar.

Maka tidaklah aneh bila kapal yang terdaftar, dengan ukuran $20 \mathrm{~m}^{3}$ (dua puluh meter kubik) dapat dibebani dengan Hipotek. ${ }^{7}$ Moch Isnaeni mengungkapkan: "Sesuai kewenangan yang dimiliki oleh pembentuk undang-undang, maka ditetapkanlah bahwa kapal dengan bobot kotor tidak kurang dari 20 $\mathrm{m}^{3}$, kalau dijadikan agunan, lembaga hipotek yang digunakan. Seluk beluk jaminan kapal ini dalam WvK diatur mulai Pasal 314 sampai dengan 315e."

Saat ini ketentuan mengenai Hipotek kapal laut telah berubah yaitu pengaturannya dikhususkan dalam UU Pelayaran. Hadirnya UU Pelayaran mengakibatkan ketentuan ukuran kapal yang dapat dijadikan sebagai obyek jaminan Hipotek mengalami perubahan, ukuran kapal laut yang dapat didaftarkan dan dibebani Hipotek bukanlah lagi $20 \mathrm{~m}^{3}$ (dua puluh meter kubik), melainkan berubah menjadi tonase kotor sekurang-kurangnya 7 GT (tujuh gross tonnage). Syarat pendaftaran kapal dalam UU Pelayaran diatur melalui Pasal 158 ayat (2), yang menyatakan bahwa kapal yang dapat didaftarkan di Indonesia yaitu: 1) Kapal dengan ukuran tonase kotor sekurang-kurangnya GT 7 (Tujuh Gross Tonnage); 2) Kapal milik Warga Negara Indonesia atau badan hukum yang didirikan berdasarkan hukum Indonesia dan berkedudukan di Indonesia dan; 3) Kapal milik badan hukum Indonesia yang merupakan usaha patungan yang mayoritas sahamnya dimiliki oleh Warga Negara Indonesia.

Berkaitan dengan pembuatan akta Hipotek oleh Pejabat Pembuat dan Pencatat Baliknama Kapal (selanjutnya disebut P3BK) sebagai syarat sahnya lahir jaminan Hipotek, maka setiap kapal laut yang akan dipasangkan akta Hipotek harus didaftarkan

\footnotetext{
${ }^{6}$ Fani Martiawan Kumara Putra. (2012). loc.cit. ${ }^{7}$ ibid.

${ }^{8}$ Moch. Isnaeni, op.cit., h. 76.
} 
kepada P3BK. Akan tetapi dalam praktiknya para pihak sebelum menghadap P3BK cenderung membuat suatu akta yang dinamakan Surat Kuasa Memasang Hipotek (selanjutnya disingkat SKMH).

SKMH ini dapat dibuat di bawah tangan, atau dihadapan Notaris, SKMH ini dibuat karena akta Hipotek buatan P3BK dirasa tidak mampu memberikan perlindungan yang cukup bagi kreditor, akta Hipotek buatan P3BK ini hanya mencantumkan hal-hal yang umum saja. Para pihak tersebut membuat satu akta khusus (SKMH) yang dapat lebih melindungi para pihak, akta tersebut ditujukan untuk mengakomodasi keinginan para pihak (debitor dan kreditor) yang tidak tercantum dalam standar akta Hipotek yang disediakan oleh P3BK. Setelah membuat SKMH, baru kemudian SKMH tersebut dijadikan satu dengan akta Hipotek buatan P3BK. ${ }^{9}$

Apabila diperhatikan, di dalam SKMH terdapat beberapa klausula-klausula, sekaligus janji-janji. Klausula atau janji-jani yang dimaksud meliputi: 1) Janji untuk menjual atas kemauan sendiri (Beding van Eigenmachtige Verkoop); 2) Janji Sewa (Huur Beding); 3) Janji Pengosongan; 4) Janji Asuransi (Assurantie Beding); 5) Janji tidak dibersihkan (Beding van Niet Zuivering); 6) Janji Hipotek berlanjut (Kredit Hipotek); 7) Klausula Kuasa untuk menyimpan asli Grosse Akta Pendaftaran Kapal; 8) Klausula Perlekatan; 9) Janji tidak mengubah bentuk.

Terlihat dalam penyebutan isi SKMH di atas bahwa ada pencantuman mengenai janji untuk menjual atas kemauan sendiri. Hal tersebut berkaitan dengan kegiatan pelaksanaan sita eksekusi atas objek jaminan. Janji menjual atas kemauan sendiri ini berisi suatu janji mengenai penjualan obyek yang dijaminkan, dan janji bahwa kreditor yang akan menerima uang hasil penjualan atas objek tersebut untuk diperhitungkan dengan hutang debitor kepada kreditor, jika terjadi resiko kerugian terhadap kapal yang dibebani Hipotek.

\section{Eksekusi Kapal Laut Sebagai Obyek Jaminan Hipotek}

Berdasarkan pengaturan yang berlaku di Indonesia, ternyata pengaturan yang ada tidaklah

${ }^{9}$ Fani Martiawan Kumara Putra. (2013). "Benturan Antara Kreditor Previlege Dengan Kreditor Preferen Pemegang Hipotek Kapal Laut Terkait Adanya Force Majeure". Jurnal Perspektif. 18(1), 32-45. cukup dapat memberikan perlindungan hukum kepada pihak-pihak terkait kapal laut tersebut. Dalam suatu perjanjian hutang piutang yang terletak jaminan kebendaan didalamnya, maka eksekusi dapat menjadi salah satu fasilitas bagi kreditor dalam hal pelunasan hutang saat hutang tersebut sudah dapat ditagih sedangkan debitornya wanprestasi. ${ }^{10}$

Hal ini sebagaimana diungkapkan oleh Sri Soedewi bahwa: "Dalam hubungan perutangan dimana ada kewajiban berprestasi dari debitor dan hak atas prestasi dari kreditor, hubungan hukum akan lancar terlaksana jika masing-masing pihak memenuhi kewajibannya."

Namun dalam hubungan perutangan yang sudah dapat ditagih (opeisbaar) jika debitor tidak melaksanakan prestasi dengan sukarela, kreditor mempunyai hak untuk menuntut pemenuhan piutangnya (hak eksekusi) terhadap harta kekayaan debitor yang dipakai sebagi jaminan. Mengenai cara pelaksanaan eksekusi, dikenal dengan tiga cara, antara lain yaitu:

1) Melalui Titel Eksekutorial: a) Eksekusi ini wajib melalui pengadilan, eksekusi ini didasarkan pada irah-irah suatu sertifikat atau grosse akta yang bertuliskan "Demi Keadilan Berdasarkan Ketuhanan Yang Maha Esa”, di mana irah-irah tersebut mempunyai kekuatan hukum yang sama dengan putusan pengadilan yang berkekuatan hukum tetap; b) Karena pencantuman irahirah itu berdasarkan undang-undang, maka hak eksekusi ini lahirnya dari undang-undang; c) Eksekusi ini harus dilakukan melalui penjualan di muka umum atau lelang;

2) Melalui Parate Eksekusi: a) Eksekusi ini tidak perlu melalui pengadilan, eksekusi ini disebut dengan kuasa menjual, maksudnya adalah adanya pencantuman janji dalam perjanjian jaminan antara debitor dan kreditor, bahwa kreditor diberikan kuasa oleh debitor untuk menjual benda jaminannya atas kuasanya sendiri. Sebaliknya, bilamana tidak diperjanjikan, maka tidak ada eksekusi melalui parate eksekusi; b)

${ }^{10}$ Fani Martiawan Kumara Putra. (2016). "Karakteristik Pembebanan Jaminan Fidusia Pada Benda Persediaan dan Penyelesaian Sengketa Saat Debitor Wanprestasi”. Jurnal Perspektif. 21(1), 34-47.

${ }^{11}$ Sri Soedewi. (2007). Hukum Jaminan di Indoneisa, Pokok-Pokok Hukum Jaminan dan Perorangan. Yogyakarta: Liberty, h. 31. 
Eksekusi ini harus dilakukan melalui penjualan dimuka umum atau lelang;

3) Melalui Penjualan di Bawah Tangan: a) Eksekusi ini dilakukan dengan kesepakatan antara debitor dan kreditor dengan cara mencari pembeli yang mau membeli dengan harga tinggi. Eksekusi ini dengan pertimbangan bahwa bilamana melalui lelang, akan memakan biaya yang lebih, dan dengan cara ini bisa lebih mendapatkan harga yang tinggi. ${ }^{12}$

Keterangan tersebut di atas sedasar dengan apa yang diungkapkan oleh Sri Soedewi dalam bukunya, yaitu: "Wewenang kreditor untuk melakukan eksekusi secara langsung terhadap benda jaminan itu karena adanya dua kemungkinan: (1) karena grosse akta mempunyai kekuatan eksekutorial, jadi dapat dilakukan eksekusi dengan dijual di muka umum; (2) karena adanya janji menjual atas kekuasaan sendiri yang tertulis dalam akte, yang berarti kreditor dapat menjual benda jaminan itu di muka umum atas dasar parate eksekusi. Dalam praktiknya, prosedur penjualan umum tidak berjalan dengan lancar dan banyak menimbulkan kerugian baik bagi kreditor atau debitor karena biaya penjualan umum yang cukup tinggi, oleh karena itu dalam praktek eksekusi itu sering dilakukan dengan penjualan di bawah tangan."13

Sebelum dilakukannya eksekusi tersebut hukum memberikan beberapa cara pemenuhan pembayaran utang yang dapat ditempuh kreditor apabila debitor melakukan cidera janji atau wanprestasi.

Diantaranya terdapat proses litigasi, Parate Eksekusi (kuasa menjual), Titel Eksekutorial, dan Penjualan di bawah tangan. Eksekusi melalui proses Litigasi membuka peluang pemegang Hipotek kapal laut untuk menempuh pemenuhan hutang melalui jalan sesuai dengan Pasal 118 jo. Pasal 121 HIR jika menghendaki, yaitu: a) Mengajukan gugatan perdata (contentious), kepada Pengadilan Negeri sesuai dengan patokan kompetensi relative yang digariskan Pasal 118 HIR, di mana nantinya akan menarik debitor sebagai pihak tergugat; b) Melalui gugatan itu, akan dilakukan pemerikasaan persidangan sesuai dengan sistem kontradiktor, yang diawali dengan tahap jawaban, replik, duplik, pembuktian dan konklusi serta penjatuhan putusan;

\footnotetext{
${ }^{12}$ Fani Martiawan Kumara Putra. (2012). loc.cit.

${ }^{13}$ Sri Soedewi, op.cit., h. 35.
}

c) Setelah adanya putusan dari Pengadilan Negeri, terdapat upaya hukum banding dan kasasi, dan bukan Peninjauan Kembali. ${ }^{14}$

Berkaitan dengan metode melalui litigasi ini, Yahya Harahap mengatakan: Karena upaya ini dirasa sangat lama dan cukup menghabiskan waktu, maka sekiranya berpatokan pada SEMA No. 6 Tahun 1992 (21 Oktober 1992) yang mengharuskan penyelesaian perkara di Pengadilan Negeri dan Pengadilan Tinggi masing-masing dalam waktu 6 (enam) bulan, berarti penyelesaian perkara pada tingkat pertama dan banding sudah memakan waktu 1 (satu) tahun. Sedangkan penyelesaiannya dalam peradilan Kasasi dan Peninjauan Kembali sangat sulit untuk diprediksi, bisa 3 (tiga) hingga 5 (lima) tahun." 15

Metode yang kedua yaitu dengan mengajukan proses eksekusi ke pengadilan melalui titel eksekutorial. Dalam Hipotek, metode eksekusi ini diatur dalam Pasal 224 HIR Jo. Pasal 195 HIR. Berdasarkan Pasal 224 HIR irah-irah terdapat dalam grosse akta Hipotek, apabila tercantum Demi Keadilan Berdasarkan Ketuhanan Yang Maha Esa, maka pada Hipotek melekat kekuatan eksekutorial (executoriale kracht) karena undang-undang sendiri mempersamakannya dengan putusan hakim atau keadilan yang berkekuatan hukum tetap. ${ }^{16}$ Dengan demikian apabila debitur melakukan cedera janji, kreditor dapat langsung meminta fiat eksekusi, baik secara lisan maupun tertulis kepada Ketua Pegadilan berdasarkan Pasal 224 Jo. Pasal 195 dan Pasal 196 HIR.

Yahya Harahap menjabarkan bahwa Ketua Pengadilan Negeri dalam hal ini akan mengambil tindakan, diantaranya: a) Memanggil debitor menghadiri sidang insidentil sesuai dengan Pasal 196 HIR, dengan tahap memperingatkan (aanmaning) debitur supaya melunasi pembayaran hutang secara sukarela, yang memiliki masa tenggang sampai dengan 8 (delapan) hari; b) Apabila batas waktu peringatan yang diberikan sudah melewati waktu yang telah diberikan, namun debitur tidak juga melaksanakan pemenuhan secara sukarela, selanjutnya Ketua Pengadilan Negeri akan mengeluarkan Sita Eksekusi atas objek Hipotek

${ }^{14}$ Yahya Harahap. (2000). Ruang Lingkup Permasalahan Eksekusi Bidang Perdata. Jakarta: Sinar Grafika, h. 231.

15 ibid., h. 231.

${ }^{16}$ ibid., h. 232. 
sesuai dengan Pasal 197 HIR. Dalam hal ini penyitaan akan dilakukan oleh Panitera atau Juru Sita sesuai dengan ketentuan Pasal 558-579 Reglement of de Rechtsvordering (selanjutnya disebut RV) yang akan dibantu oleh dua orang saksi yang akan membuat Berita Acara Penyitaan yang selanjutnya akan diumumkan dengan cara didaftarkan di kantor Syahbandar yang bersangkutan sesuai dengan Pasal 198 HIR; c) Kewenangan Ketua Pengadilan Negeri selanjutnya sesuai dengan Pasal 200 HIR akan menerbitkan Penetapan Penjualan Lelang yang akan dibantu oleh Kantor Lelang sekaligus sebagai perantara penjualan lelang tersebut. ${ }^{17}$

Keuntungan dari proses eksekusi ini adalah waktu yang dibutuhkan tidak terlalu lama seperti penyelesaian melalui proses litigasi seperti penjelasan di awal. Memang mungkin saja timbul hambatan pelaksanaan eksekusi berupa perlawanan pihak debitor atau perlawanan pihak ketiga, namun hal itu tidak akan menghalangi atau menunda pelaksanaan eksekusi, kecuali dalam hal yang sangat eksepsional sekali. $^{18}$

Selanjutnya adalah proses Parate Eksekusi atau dapat disebut penjualan lelang oleh kreditor berdasarkan kuasa sendiri (eigenmachtige verkoopI). Dalam Hipotek hal ini didasarkan Pasal 1178 ayat (2) BW. Syarat-syarat untuk melakukan Parate Eksekusi adalah dalam kuasa tersebut harus dituangkan sebagai klausul dalam akta Hipotek yang berisi pernyataan, bahwa debitor memberikan hak atau kuasanya kepada kreditor untuk menjual sendiri objek barang Hipotek, apabila debitor cedera janji, selanjutnya pelaksanaan penjualan tanpa adanya campur tangan dari Pengadilan Negeri, tetapi tata cara penjualan harus tetap tunduk pada Pasal 1211 $\mathrm{BW}$, yaitu penjualan harus dilakukan di muka umum, dan Kreditor meminta bantuan Kantor Lelang untuk melakukan penjualan lelang. ${ }^{19}$

Proses yang ketiga adalah proses penjualan di bawah tangan. Sebenarnya dalam Hipotek, penjualan di bawah tangan ini tidak ada pengaturannya, namun berdasarkan pendapat dari Sri Soedewi sebelumnya mengenai metode eksekusi, serta dengan pendekatan analog melalui model eksekusi dalam UUHT, dalam Hipotek yang penjualan di bawah tangan ini

\footnotetext{
17 ibid., h. 234.

18 ibid.

19 ibid., h. 236.
}

tidak ada pengaturannya kini dapat diambil jalan keluarnya. Yahya Harahap dengan ini menyatakan: "Melalui pendekatan secara analog dengan ketentuan Pasal 20 UUHT, maka dari itu dapat dibenarkan penjulan Hipotek kapal laut di bawah tangan. Cara pelaksanaan sepenuhnya berpedoman pada ketentuan yang digariskan Pasal 20 UUHT yaitu: a) Harus berdasarkan kesepakatan antara debitor dengan kreditor, sesuai dengan ketentuan Pasal 20 ayat (2) UUHT, kesepakatan penjualan di bawah tangan baru dapat dilaksanakan setelah terjadi wanprestasi. Tidak boleh disepakati dalam akta Hipotek; b) Bentuk kesepakatan harus tertulis (is writing), boleh berbentuk akta autentik dan dapat juga akta di bawah tangan; c) Diperkirakan dapat diperoleh harga yang lebih tinggi; d) Pelaksanaan penjualan di bawah tangan berpedoman pada Pasal 20 ayat (3) UUHT, yaitu setelah lewat waktu 1 (satu) bulan dari tanggal pemberitahuan secara tertulis oleh pemberi atau pemegang Hipotek, diumumkan sedikit-sedikitnya dalam dua surat kabar, dan tidak ada pihak yang merasa keberatan. ${ }^{20}$

Kebolehan penjualan di bawah tangan, bukan hanya diatur dalam UUHT. Dalam jaminan fidusia pun dibenarkan juga penjualan fidusia di bawah tangan (Pasal 29 ayat (1) huruf c jo. ayat (2) UUJF), tata cara dan penerapannya pun hampir sama dengan Pasal 20 UUHT. Ditambahkan oleh Yahya Harahap sebagai berikut: "Bertitik tolak dari ketentuan yang membolehkan objek hak tanggungan dan jaminan fidusia dapat dijual di bawah tangan, memperkuat alasan kebolehan penjualan di bawah tangan objek Hipotek kapal laut melalui penerapan secara analog dengan Pasal 20 ayat (2) dan (3) UUHT dan Pasal 29 ayat (1) huruf c dan ayat (2) UUJF."21

Sedasar dengan telaah di atas, maka kreditor dalam hal hutang piutang yang disertai dengan adanya jaminan, memiliki bahkan hingga 3 (tiga) cara dalam melakukan eksekusi yang memiliki kelebihan dan kekurangannya masing-masing, semata-mata hanya untuk mendapatkan pelunasan hutangnya. Dalam hal Hipotek, eksekusi melalui titel eksekutorial ternyata tidak selalu berjalan dengan lancar melainkan terdapat hambatan-hambatan. Hambatan yang kerap terjadi yaitu pada tahapan sita eksekusi obyek jaminan kapal laut tersebut.

\footnotetext{
20 ibid., h. 238.

21 ibid.
} 


\section{Kendala Sita Eksekusi Kapal Laut Sebagai Objek Jaminan}

Saat debitor tidak melaksanakan kewajibannya, maka kreditor dapat mengajukan gugatannya ke Pengadilan, Pengadilan akan mengeluarkan peringatan (aanmaning), bila aanmaning tersebut telah melewati batas, maka sudah barang tentu Ketua Pengadilan Negeri akan menerbitkan Penetapan Sita Eksekusi berdasar Pasal 197 ayat (1) HIR.

Penerapan sita eksekusi dalam keadaan kapal tersebut sedang melakukan kegiatan operasional baik itu di dalam atau di luar negeri, dan eksekusi itu diajukan melalui Pengadilan, maka eksekusi tersebut haruslah ditangguhkan terlebih dahulu, hal ini karena adanya pengaturan dalam Reglement op de Burgerlijke Rechtsvordering (RV), khususnya Pasal 559, 560, 651, dan $577 \mathrm{Rv}$.

RV pada saat ini memang sudah tidak lagi berlaku, namun seharusnya walaupun suatu aturan itu sudah tidak berlaku, namun prinsip-prinsip di dalam aturan tersebut setidaknya masih dapat dijadikan pertimbangan Hakim dalam memutus perkara. Saat ini Hakim masih sering merujuk pada prinsip-prinsip dalam RV untuk memutus perkara. Mengenai hal ini L. Sumartini memaparkan: "Terkadang untuk melaksanakan hukum materiil yang diatur dalam BW, baik itu HIR/Rbg tidak selalu mempunyai peraturanperaturan yang diperlukan, sehingga diperlukan bagi hakim untuk melirik aturan yang lain dalam hukum acara perdata, aturan yang dipertimbangkan adalah apa yang ada dalam RV, karena memang substansi dari RV lebih komprehensif sebagaimana awal mulanya dipergunakan unuk orang-orang yang cukup berkembang, yaitu orang-orang Eropa, justru pengaturan yang komprehensif seperti ini yang selayaknya menjadi pendampingnya BW. Oleh karenanya masih sering diterapkan, dipertahankan dan dijadikan pedoman bagi hakim sebagai pelengkap karena tidak diaturnya dalam HIR."22

Berdasarkan pengaturan dalam Pasal 559, 560, 651 dan $577 \mathrm{Rv}$ tersebut, timbul 2 (dua) asas dalam penerapan sita obyek jaminan yang berkaitan dengan kapal laut, yaitu: 1) Asas Rijdende Beslag; dan 2) Asas Kebebasan Menguasai dan Menguasai Kapal.

${ }^{22}$ L. Sumartini, Nurslaam Sianipar, Tana Mantriri, et.al. (1998). Penelitian Hukum tentang Faktor-Faktor Penyebab Kelambatan Eksekusi Putusan Hakim. Jakarta: Badan Pembinaan Hukum Nasional Departemen Kehakiman, h. 10.
Pasal 559 Rv menegaskan prinsip penyitaan atas kapal, yaitu yang boleh disita eksekusi (executoriale beslag) hanya terbatas sarana kapalnya dan sita jaminan atau sita eksekusi atas kapal, tidak boleh menghambat kegiatan perusahaan atau tidak boleh mematikan kegiatan operasional perusahaan debitor.

Yahya Harahap dalam hal ini berpendapat bahwa: "Memperhatikan prinsip Rijdende Beslag yang disebutkan dalam Pasal 559 Rv, sita eksekusi yang diletakkan atas kapal, tidak boleh menghalangi atau menghambat kegiatan operasional kapal untuk berlayar di dalam wilayah Indonesia, maupun ke luar negeri. Meskipun telah disita, kapal tetap bebas berlayar kemana saja yang dikehendaki debitor." ${ }^{23}$

Pasal 560 Rv memerintahkan kepada juru sita untuk mengangkat seorang penjaga atau penyimpan di atas kapal, namun terlepas dari kebolehan melakukan sita eksekusi atas kapal, penyitaan atas kapal tidak boleh: a) Menghalangi dan mengurangi hak penguasaan debitor (pemilik) atas kapal; b) Mengurangi dan membatasi hak pengusahaan debitor atas kapal. ${ }^{24}$

Selanjutnya dalam Pasal 577 ayat (1) dan (2) Rv, dilarang menyita kapal yang siap berlayar, menurut Pasal ini, sita jaminan maupun sita eksekusi tidak dapat diletakkan atas kapal sesuai dengan prinsip: 1) Bilamana kapal telah siap untuk berlayar, dilarang meletakkan sita diatasnya, meskipun telah ada izin atau penetapan Ketua Pengadilan Negeri. Larangan ini bertujuan untuk menghindari kerugian yang akan dialami debitor (pemilik) maupun pihak lain yang mengadakan perjanjian dengan pemilik. (Pasal 577 ayat (1) Rv); 2) Kapal dianggap siap berlayar apabila pemimpin kapal dilengkapi dengan suratsurat yang diperlukan agar kapal dapat berlayar, dan terhitung sejak surat-surat lengkap, undang-undang menganggap kapal sudah berada dalam keadaan siap untuk berlayar, sehingga pada kapal itu melekat larangan sita diatasnya (Pasal 577 ayat (2) Rv). ${ }^{25}$

\section{PENUTUP}

\section{Kesimpulan}

Eksekusi kapal laut sebagai obyek jaminan dapat dilakukan dengan berbagai cara, diantaranya yang sering diminati adalah dengan mengajukan proses

\footnotetext{
${ }^{23}$ Yahya Harahap, op.cit., h. 239.

${ }^{24}$ ibid., h. 240.

${ }^{25}$ ibid.
} 
eksekusi ke pengadilan melalui titel eksekutorial. Dalam Hipotek, metode eksekusi ini diatur dalam Pasal 224 HIR jo. Pasal 195 HIR. Berdasarkan Pasal 224 HIR irah-irah terdapat dalam grosse akta Hipotek, apabila tercantum Demi Keadilan Berdasarkan Ketuhanan Yang Maha Esa, maka pada Hipotek melekat kekuatan eksekutorial (executoriale kracht) karena undang-undang sendiri mempersamakannya dengan putusan hakim atau keadilan yang berkekuatan hukum tetap. Dengan demikian apabila debitur melakukan cedera janji, kreditor dapat langsung meminta fiat eksekusi, baik secara lisan maupun tertulis kepada Ketua Pegadilan berdasarkan Pasal 224 jo. Pasal 195 dan Pasal 196 HIR. Namun cara tersebut tidak selalu lancar, hambatan pada sita eksekusi baik itu saat kapal berada dalam perairan dalam yurisdiksi negara bendera kapal, atau di luar yurisdiksi. Hambatan tersebut timbul dari prinsipprinsip yang ada dalam Rv yang mengatur khusus mengenai sita eksekusi kapal laut yang mana tidak diatur dalam HIR.

\section{Rekomendasi}

Sebaiknya segera dibentuk suatu aturan baru yang mendukung aktifitas kemaritiman, agar dapat lebih menjamin kepastian hukum para pihak dalam penjaminan, khususnya pihak kreditor.

\section{DAFTAR PUSTAKA}

\section{Peraturan Perundangan-undangan:}

Undang-Undang Nomor 17 Tahun 2008 tentang Pelayaran.

Undang-Undang Nomor 42 Tahun 1999 tentang Jaminan Fidusia.

Undang-Undang Nomor 4 Tahun 1996 tentang Hak Tanggungan.
Undang-Undang Nomor 7 Tahun 1992 sebagaimana telah dirubah dengan Undang-Undang Nomor 10 Tahun 1998 tentang Perbankan.

\section{Buku:}

Mariam Darus Badrulzaman. (1983). Beberapa Masalah Hukum dalam Perjanjian Kredit Bank dengan Jaminan Hipotek serta HambatanHambatannya dalam Praktek di Medan. Bandung: Alumni.

Yahya Harahap. (2000). Ruang Lingkup Permasalahan Eksekusi Bidang Perdata. Jakarta: Sinar Grafika.

Moch. Isnaeni. (1996). Hipotek Pesawat Udara Di Indonesia. Surabaya: Dharma Muda.

L. Sumartini, Nurslaam Sianipar, Tana Mantriri, et.al. (1998). Penelitian Hukum tentang Faktor-Faktor Penyebab Kelambatan Eksekusi Putusan Hakim. Jakarta: Badan Pembinaan Hukum Nasional Departemen Kehakiman.

Sri Soedewi. (2007). Hukum Jaminan di Indoneisa, Pokok-Pokok Hukum Jaminan dan Perorangan. Yogyakarta: Liberty.

\section{Jurnal Ilmiah:}

Fani Martiawan Kumara Putra. (2012). "Surat Kuasa Memasang Hipotek Dalam Jaminan Hipotek Kapal Laut”. Jurnal Perspektif. 17(2), 98-107. (2013). "Benturan Antara Kreditor Previlege Dengan Kreditor Preferen Pemegang Hipotek Kapal Laut Terkait Adanya Force Majeure", Jurnal Perspektif. 18(1), 32-45. . (2016). "Karakteristik Pembebanan Jaminan Fidusia Pada Benda Persediaan dan Penyelesaian Sengketa Saat Debitor Wanprestasi”. Jurnal Perspektif. 21(1), 34-47. 